\title{
Correlation of MT levels in livers and gills with heavy metals in wild tilapia (Oreochromis mossambicus) from the Klang River, Malaysia
}

\begin{abstract}
Metallothionein (MT) concentrations in gill and liver tissues of Oreochromis mossambicus were determined to assess biological response of fish to levels of some metals. Metal concentrations in gill and liver tissues of $\mathrm{O}$. mossambicus ranged from 0.6 to 2.6 for $\mathrm{Cd}, 16$ to 52 for $\mathrm{Zn}, 0.5$ to 17 for $\mathrm{Cu}$ and 2 to 67 for $\mathrm{T}-\mathrm{Hg}$ (all in $\mu \mathrm{g} / \mathrm{g}$ wet weight, except for $\mathrm{T}-\mathrm{Hg}$ in $\mathrm{ng} / \mathrm{g}$ wet weight). Accumulation of $\mathrm{Cd}, \mathrm{Zn}, \mathrm{Cu}$ and $\mathrm{Hg}(\mu \mathrm{g} / \mathrm{g}$ wet weight) in the liver and gills of $\mathrm{O}$. mossambicus were in the order of liver > gills. The concentrations of $\mathrm{Cd}, \mathrm{Zn}, \mathrm{Cu}$ and $\mathrm{Hg}$ in fish tissues were correlated with MT content. The increases in MT levels from the reference area Puchong Tengah compared to the polluted area Kampung Seri Kenangan were 3.4- and 3.8-fold for gills and livers, respectively. The results indicate that MT concentrations were tissue-specific, with the highest levels in the liver. Therefore, the liver can act as a tissue indicator in O. mossambicus in the study area.
\end{abstract}

Keyword: Metallothionein; Oreochromis mossambicus; Liver; Gill; Malaysia 